\title{
NEW DOUBLE-CRESTED CORMORANT COLONIES IN SASKATCHEWAN
}

\author{
PAUL C. JAMES and KEITH RONEY, Saskatchewan Museum of Natural \\ History, Wascana Park, Regina, Saskatchowan. S4P 3V7
}

While on other museum-related activities on 8 July 1990, we discovered three new Double-crested Cormorant colonies in northern Saskatchewan. All were first spotted from an aircraft and were photographed, thus permitting nest counts. The first colony of 30 nests was on a small island off the north shore of Peter Pond Lake. We could not locate the island on the 1:50,000 map sheet and concluded that it had recently appeared. The second and third colonies were found on Wasekamio Lake. One colony, located in Gregory Bay, held 121 nests and the other, east of Sebestyen Island, held 70 nests. In addition, the number of islands which held cormorant colonies on Churchill Lake had also increased from seven in $1985^{2}$ to perhaps 10 to 12 , although we did not conduct an exact count.
The last census of Saskatchewan cormorant colonies was carried out in 1985. ${ }^{1}$ At that time, the cormorant population of 26 colonies had increased almost $52 \%$ over that of $1982 .{ }^{2}$ Some of the largest increases occurred at Churchill Lake, close to the newlyfound colonies reported here. It would appear that the increase in cormorants in the north is continuing, although a province-wide survey is clearly neoded.

1. RONEY, K. and M. HLADY. 1984. 1982 census of Saskatchewan White Pelican and Double-crested Cormorant colonies. Blue Jay 42:77-82.

2. - 1986. 1985 census of pelican and cormorant colonies in Saskatchewan. Blue Jay 44:177-79.

\section{BEGINNER'S MIND}

Let us not limit ourselves by pretending to understand this planet or the miracle which drives it.

We are prejudiced by the scale of things.

How does the body look to a microorganism?

Is "thought" peculiar to the human brain?

Do cells feel? Do flowers see their own colors?

What does the river know? Do stones carny memories?

F. Lehman. 1988. The sacred landscape. Celestial Arts, Berkley, CA. 